\title{
PARASITIC CASTRATION OF TRIDACNA MAXIMA (MOLLUSCA:BIVALVIA) BY BUCEPHALID LARVAE (TREMATODA: DIGENEA) IN THE NORTHERN RED SEA
}

\author{
Reda M. El-Said Hassanine \\ Department of Biology, New Valley Faculty of Education, Assuit \\ University, El-Kharga, New Valley, Egypt
}

Key words: Digenean trematodes, Bucephalidae, parasitic castrationMollusca, Bivalvia, Tridacna maxima, Red Sea.

\begin{abstract}
In late winter 2000, 160 mature individuals of the hermaphroditic giant clam Tridacna maxima (Bivalvia: Tridacnidae) were collected as a random sample from a wild bed inhabiting the coasts of Sharm El-Sheikh, Northern Red Sea, Egypt. Examination revealed that the gonads of 36 individuals $(22.5 \%)$ were castrated by the sporocysts and cercariae of a bucephalid trematode species (Digenea: Bucephalidae). Although the prevalence was moderate, its effect on the reproductive capacity of these clams was significant, since the gonads of 21 individuals $(13.13 \%)$ were heavily infected and completely castrated, while those of 15 individuals $(9.37 \%)$ were slightly infected and partially castrated. Sporocysts and cercariae were described and figured, and the mechanism of parasitic castration was discussed. It was concluded that such parasitic castration may harmly affect the overall fecundity of the whole population of $T$. maxima inhabiting the coasts of Sharm El-Sheikh; and possibly other areas the Northern Red Sea.
\end{abstract}

\section{INTRODUCTION}

Digenean trematodes of the Red Sea fishes are poorly known in the literature. However, in Egypt, mature forms of several species were collected from their definitive fish hosts and described in series of taxonomical papers by Nagaty (1937:1973), Nagaty and AbdelAal (1961 : 1969), Ramadan (1982 : 1986), and Shalaby and Hassanine (1996: 1997), but the larval stages of these parasites are not so far described, and no attempt was made to explore their pathogenic 
effects on their intermediate molluscan hosts, which were not yet completely recognized.

Sometimes, the larval stages of digenean trematodes infect the gonads of their intermediate molluscan hosts, where they inhibit the process of gametogenesis. This condition, referred to as parasitic castration, a disease common in snails and bivalves and usually leads to their sterility. Eariier studies on the effect of parasitic castration were listed by Baudoin (1975); and more recent studies include those by Sanders and Lester (1981), Hughes and Answer (1982), Rader (1982), Cheng et al. (1983), Joosse and Van Elk (1983), Sousa (1983). Huffman (1985). Pearson and Cheng (1985), Sullivan et al. (1985), De Jong-Brink et al. (1986), Kabat (1986), Shelley et al. (1988). Coustau et al (1991), and Rohde (1993).

Bucephalidae Poche, 1907 is a large family created to include all the digenean trematodes of fishes which possess no suckers. instead they have a rhynchus (adhesive organ) at theil anterior ends. Of this family, the larval stages of several species were found to be highly castrators to their intermediate molluscan hosts (Shelley et al.. 1988).

In the present study, parasitic castration was recorded for the first time from the Red Sea. where some individuals in a wild bed of the hermaphroditic giant clam Tridacna maxima were found severely infected in their gonads and hence castrated by the larval stages of a bucephalid trematode species.

\section{MATERIAL AND METHODS}

In late winter 2000,160 mature individuals of the hermaphroditic giant clam Tridacna maxima were collected as a random sample from a wild bed inhabiting the coasts of Sharm ElSheikh, Northern Red Sea, Egypt (Fig. 1). The gonad of each clam was dissected from the visceral mass, and preliminary examined by using the light microscope to determine the presence or absence of the trematode larvae (sporocysts and cercariae). In their presence, some of which were carefully liberated from the infected gonad, fixed in alcohol-formalin-acetic (AFA), and preserved in $70 \%$ ethyl alcohol. Whole mounts were stained by alum carmine, cleared in terpineol, mounted in Canada balsam, and drawn with the aid of a camera lucida. For histological examination, the infected gonads of clams were fixed in $10 \%$ formalin in sea water for 24 hours prior to storige 
in $70 \%$ ethyl alcohol. Tissue blocks taken from the approximate center of the gonad, were processed to paraffin wax, sectioned at $7 \mu \mathrm{m}$, stained by Ehrlich's acid haemotoxylin and counter-stained by eosin.

\section{RESULTS}

The main characteristics of the trematode larvae collected from the infected gonads of T. maxima are as follows:

The sporocysts (Fig. 2a):

Sporocyst is sausage-shaped and measures $3.10-3.80 \mathrm{~mm}$ long by $0.60-0.80 \mathrm{~mm}$ wide. It contains several germ balls and $10-14$ ceracariae at various stages of development.

\section{The cercariae (Fig. 2b):}

In the most developed cercaria, the body is elongate, cylindroid and measures $0.33-0.45 \mathrm{~mm}$ long by $0.10-0.14 \mathrm{~mm}$ wide. The tegument is covered with very minute sharp spines. The rhynchus is V-shaped and measures $0.07-0.10 \mathrm{~mm}$ in length; its base is surrounded by numerous gland cells. The mouth opening is situated on the ventral side of the body, nearly at its middle, and surrounded directly by a globular muscular pharynx, measuring $0.028-0.035 \mathrm{~mm}$ in diameter. The oesophagus is very short, of $0.012-0.016 \mathrm{~mm}$ in length, and opens directly into a short saccular intestine that is directed forwards in the second fourth of the body. Gonad anlagen are all in the posterior half of the body, towards the right side. Rudiments of the terminal genitalia are situated in the posterior region of the body. The tail stem is semi-triangular, and measures $0.07-0.10 \mathrm{~mm}$ in length. The tail furcae are well developed, up to twice the length of the body, and attached to the ventral surface of the anterior border of the tail stem. Gland cells which secrete a sticky substance are located along the posterior edge of the tail stem and in the furcae.

\section{Prevalence of infection:}

Out of $160 \mathrm{~T}$. maxima examined, the gonads of 36 individuals $(22.5 \%)$ were found infected with the above described sporocysts and cercariae. The level of infection ranged from slight to heavy. Generally, the gonads of 15 individuals $(9.37 \%$ of the examined 
sample corresponding to $41.67 \%$ of the infected individuals) were slightly infected, while the gonads of the other 21 individuals $(13.13 \%$ of the examined sample and $58.33 \%$ of the infected individuals) were severe in infected.

\section{Pathological effects of sporocysts and cercariae:}

The pathological effects of sporocysts and cercariae on the gunadal follicles of $T$. maxima were dependent on the level of infection. In slight infections, no gametes were observed in some testicular and ovarian follicles, since they were occupied by the sporocysts and cercariae; the remaining follicles appearing normal (partial castration). In heavy infections, the gonads were hypertrophied. and the gonadal follicles were completely replaced by homogeneous masses of sporocysts and cercariae (complete castration). Accordingly, the typical hermaphroditic structure of the gonad (Pl. 1a) was unrecognisable (Pl. 1b) due to the breakdown the normal gonadal architecture.

\section{DISCUSSION}

The above described trematode larvae were belonging to a bucephalid species, since the cercaria has a distinct rhynchus, a mouth situating near the middle of the ventral surface of the body, an unbranched intestine, and terminal genitalia situating at the posterior region of the body. These are the main taxonomic features used to differentiate the family Bucephalidae Poche, 1907 from the other digenean families of fishes.

Parasitic castration of bivalves by sporocysts and cercariae of the bucephalid trematodes has been reported by several authors (Sanders, 1966; Feng and Canzonier, 1970; Flook and Ubelaker, 1972; Tripp, 1973; Stadnichenko, 1974; Umiji et al., 1976; Koubek, 1977; Sanders and Lester, 1981; Turner, 1985; Kabat, 1986; Shelley et al., 1988; Coustau et al.,1991; and Rohde, 1993). Although the prevalence of the present bucephalid larvae in the examined sample of $T$. maxima was moderate $(22.5 \%)$, their effect on the reproductive capacity of these clams was significant, since the gonads of $13.13 \%$ of the examined individuals were severely affected, and those of $9.37 \%$ of them were partially castrated. Such suppression in the reproductive capacity, often leading to morbidity rather than mortality (Rohde, 
Parasitic castration of Tridacna maxima (Mollusca: Bivalvia) $11^{\mathrm{F}}$ by bucephalid larvae (Trematoda: Digenea) in the northern Red Sea

1993). However, it increases the ability of the parasite to act as a regulator for the host population (May, 1983). Partial castration is probably a consequence of the host's defenses (immune response to parasite: see Bayne, 1983), and would be selectively advantageous (for the host) orer complete castration. as it allows the host to continuc to reproduce, albeit at lower levels.

Many hypotheses have been proposed to explain the mechanism of parasitic castration. Cheng and Cooperman (1964, believed that parasitic castration is due to the mechanical action of the parasite, while Pearson and Cheng (1988) beliced that such castration is due to the physiological action of the parasite. In the present investigation, no apparent mechanical destruction was observed in the infected gonadal follicles of $T$. maxima, but the main observation was the disappearance of gametogenesis. The mechanism of this cffect was explained by Coustau et al. (1991), who experimentally proved that sporocysts and cercariae usually castrate the gonads of their intermediate molluscan hosts through the secretion of two factors: the first is an anti-mitotic factor inhibiting the action of the gonial-mitosis stimulating hormone, which triggers the gametogenesis in the mollusc; the second is a glycogen mobilizing factor which stimulates the mobilization of the stored glycogen from the mantle cells to the gonad, to be consumed by the trematode larvae (this glycogen wa originally stored to fuel the process of gametogenesis). Therefore, the trematode larvae obtain an optimal nutritional supply without provoking destruction of the molluscan gonad.

Finally, it was concluded that such parasitic castration may harmly affect the overall fecundity of the whole population of $T$. maxima inhabiting the coasts of Sharm El-Sheikh and possibly other areas of the Northern Red Sea. This necessitates further studies about the control of such parasites and protecting the host clams by various means. 


\section{REFERENCES}

Baudoin, M. (1975). Host castration as parasite strategy. Evolution (Lawrence, Kans), 29: 335-352.

Bayne, C. J. (1983). Molluscan immunology. In "The Mollusca".Vol. 5. Physiology, Part 2. Edited by A. S. M. Salenddin and K. M. Wilbur. Academic Press. Inc., New York. pp. 407486 .

Gustat. C.. Renand, F., Delay, B., Robbins, 1., and Mathieu. M. (1991). Mechanisms involved in parasitic castration: In vitro efficts of the trematode Prosorhynchus squamatus on the gamotogenesis and the nutrient storage metabolicm of the marine bivalve molluse Mrilus edutis. Exp. Parasitol. $73: 36-43$.

Cheng. T and Cooperman, J. S. (1964). Studies on the host-parasite relationships between larval trematodes and their hosts. $\mathrm{V}$. The invasion of the reproductive system of Helisoma trivolvis by the sporocysts and cercariae of Glypthelmins pennsylvaniensis Cheng. Trans. Amer. Microscop. Soc., 83: 12-23.

Cheng. T. C., Sullivan, J. T., Howland, K. H., Jones, T. F., and Moran, H. J. (1983). Studies on parasitic castration: Soft tissue and shell weights of Ilyanassa obsoleta (Mollusca) parasitized by larval trematodes. J. Invertebr. Pathol., 42: 143-150.

DE Jong-Brink, M., EL Saadany, M., Boer, H., and Joosse, J. (1986). Influence of trematode parasite upon reproductive activity of their intermediate hosts. In " Advances in Invertebrate Reproduction" (M. porchet, J. C. Andries and A. Dhainaut, Eds), vol. 4, pp. 163-172.

Feng, S. Y., and Canzonier, W. J. (1970). Humoral responses in the American oyster Crassostrea virginica infected with Bucephalus sp. and Minchinia nelsoni. In: A symposium on diseases of fishes and shellfishes. Amer. Fish. Soc. Spec. Publ. No 5: 497-510. 
Flook. J. M. and Ubelaker, J. E. (1972). A survey of metazoan parasites in unionid bivalves of Garza-Little Elm Reservoir, Denton County, Texas. Texas 1. Sci., 23: 381392.

Huffman, J. E. (1985). Histopathology and histochemical effects of larval trematodes in Goniobus virginica (Gastropoda: Pleuroceridae). Veliger 27: 273-281.

Hughes, R. M. and Answer, P. (1982). Growth. spawning. and trematode infection of littorina litterea (L.) from an exposed shore in North Wales. J. Molluse. Stud., 48: 321-330.

Joosse. J. and Van Kilk, R. (1983). Intervention of a trematode parasite in the action of the female gonadotrophic hormones on the albumen gland of Lymnaea stagnalis. In " Mollusca Neuro-endocrinology" (J. Lever and H. H. Boer. Ids).pp. 118-120.

Kabat, A. R. (1986). Effects of trematode parasitism on the reproductive output of the bivalve Transennella tantilla. Canad. J. Zool., 46: 267-270.

Koubek, P. (1977). The discovery of the trematode Aspidogaster conchicola new record and the cercaria of Bucephalus polymorphus in our mussels. Folia Fac. Sci. Nat. Univ. Purkynianae Brun. Biol., 18: 47-53.

May, R. M. (1983). Parasite infections as regulators of animal populations. Am. Sci., $71: 36-45$.

Nagaty, H. F. (1937). Trematodes of fishes from the Red Sea. Part 1. Studies on the family Bucephalidae Poche, 1907. Cairo: Egyptian Univ. Faculty of Medicine, Publ., 12: 1-172.

Nagaty, H. F. (1973). Trematodes of fishes from the Red Sea. Parts 1 to 20. A recapitulation. Bull. Zool. Soc. Egypt. 25: 1-13.

Nagaty, H. F., and Abdel-Aal, T. M. (1961). Trematodes of fishes from the Red Sea. Part 10. On three new 
Cryptogonimidae including two new genera. J. Parasitol., 51: $233-236$.

Nagary, H. F. and AbdeL-Aal, T. M. (1969). Trematodes of fishes from the Red Sea. Part 18. On two new and one known allocreadid species.J. Arab. Vet. Med. Ass. 29 (1/2):1-5.

Pearson, E. J. and Cheng, T. C. (1985). Studies on parasitic castration: Occurrence of a gametogenesis inhibiting factor in extracts of Zoogonius lasius (Trematoda). J. Invertebr. Pathol.. 46: 165-168.

Rader. D. N. (1982). Orthonectid parasitism: Effects on the ophiuroid, Amphipholis squamata. Proceeding of the International conference. Tampa Bay, Rotterdam. pp 395-401.

Ramadan, M. M. (1982). On two new species of lormopsolus Poche, 1926 (Trematoda: Acanthocolpidae) from the Red Sea fishes. J. Faculty of Education, Ain Shams University, Egypt. 5: 143-153.

Ramadan, M. M. (1986). Trematodes of the genera Helicometra Odhner, 1902 (Opecoelidae) and Apharyngogliauchen Yamaguti, 1942 (Gyliauchenidae) from the Red Sea fishes. Jap. J. Parasitol., 35: 483-490.

Rohde, K. (1993). Ecology of marine parasites. CAB International, Wallingford, UK. $298 \mathrm{pp}$.

Sanders, M. J. (1966). Parasitic castration of the scallop Pecten alba (Tate) by a bucephalid trematode. Nat. Lond., 212:307308 .

Sanders, M. J., and Lester, R. J. (1981). Further observations on a bucephalid trematode infection in scallops (Pecten alba) in Port Phillip Bay, Victoria. Aust. J. Mar. Res., 32: $475-$ 478 .

Shalaby, I. M. and Hassanine, R. M. (1996). Neoerilepturus aegyptensis new genus, new species (Platyhelminthes: Trematoda: Digenea) from the Red Sea fishes: Light and scanning electron microscopic description of the 
Parasitic castration of Tridacna maxima (Mollusca: Bivalvia) 119 by bucephalid larvae (Trematoda: Digenea) in the northern Red Sea

tegumental surface. J. Egypt. Ger. Soc. Zool., 2l(D): 89106.

Shalaby, I. M. and Hassanine, R. M. (1997). Cryptacetabulum aegyptensis n. gen., n. sp. (Trematoda: Digenea: Opistholebetidae) from the Red Sea fishes: As described by the light and scanning electron microscopy. J. Egypt. Ger. Soc. Zool, 2t (D): 246-259.

Shelley, C. C.; Glazebrook, J. S.; Turak, E.; Winsor, L. and DENTON, G. R. (1988). Trematode (Digenea: Bucephalidae) infection in the burrowing clam Tridacna crocea from the Great Barrier Reef. Dis. Aquat. Org., 4 : 143-147.

sousa. W. P. (1983). Host life history and the effect of parasitic castration on growth: a field study of Gerithidae californica Haldeman (Gastropoda: Prosobranchia) and its trematode parasites. J. Exp. Mar. Biol. Ecol., 73: 273296.

Sullivan, J. T., Cheng, T. C., and Howland, K. D. (1985). Studies on parasitic castration of Ilyanassa obsoleta (Mollusca: Prosobranchia) by several marine trematodes. Trans. Amer. Microscop. Soc., 104: 154- 171.

Tripp. M. R. (1973). Hermaphroditism in Bucephalus infected oysters. J. Invertebr. Pathol., 21:321-322.

Turner, H. M. (1985). Parasites of eastern oyster from subtidal reefs in a Louisiana USA estuary with a note on their use as indicators of water quality. Estuaries, 8: 323-325.

Umiji. S.; Lunetta, J. E. and Leonel, R. M. (1976). Infestation of the mussel Perna perna by digenetic trematodes of the bucephalid family genus Bucephalus. An. Acad. Bras. Cienc., 47: 115-117. 


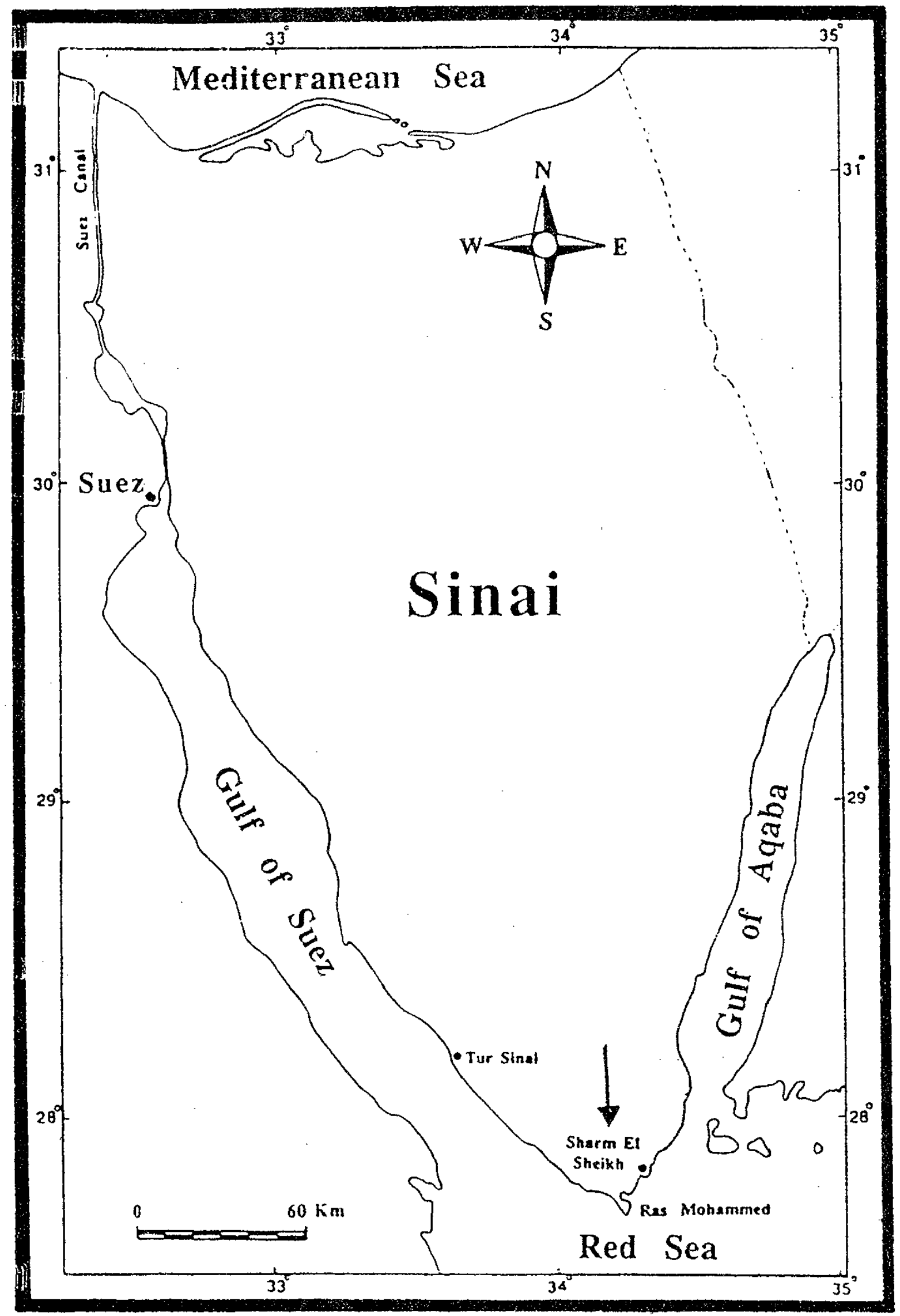

Fig. (1): Map of Sinai peninsula showing the locality ofthe examined giant ciam Tridacna maxima. 
A.

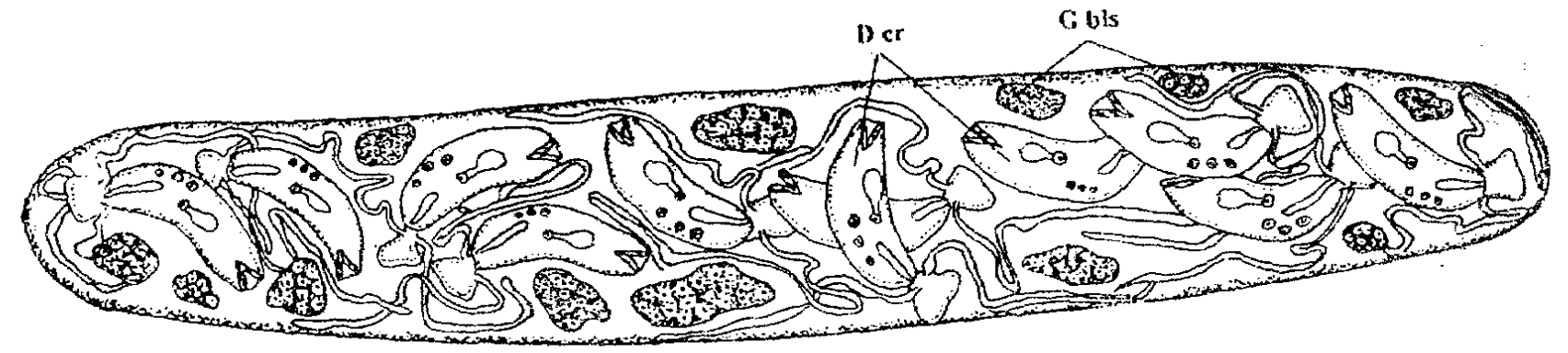

$1 \mathrm{~mm}$

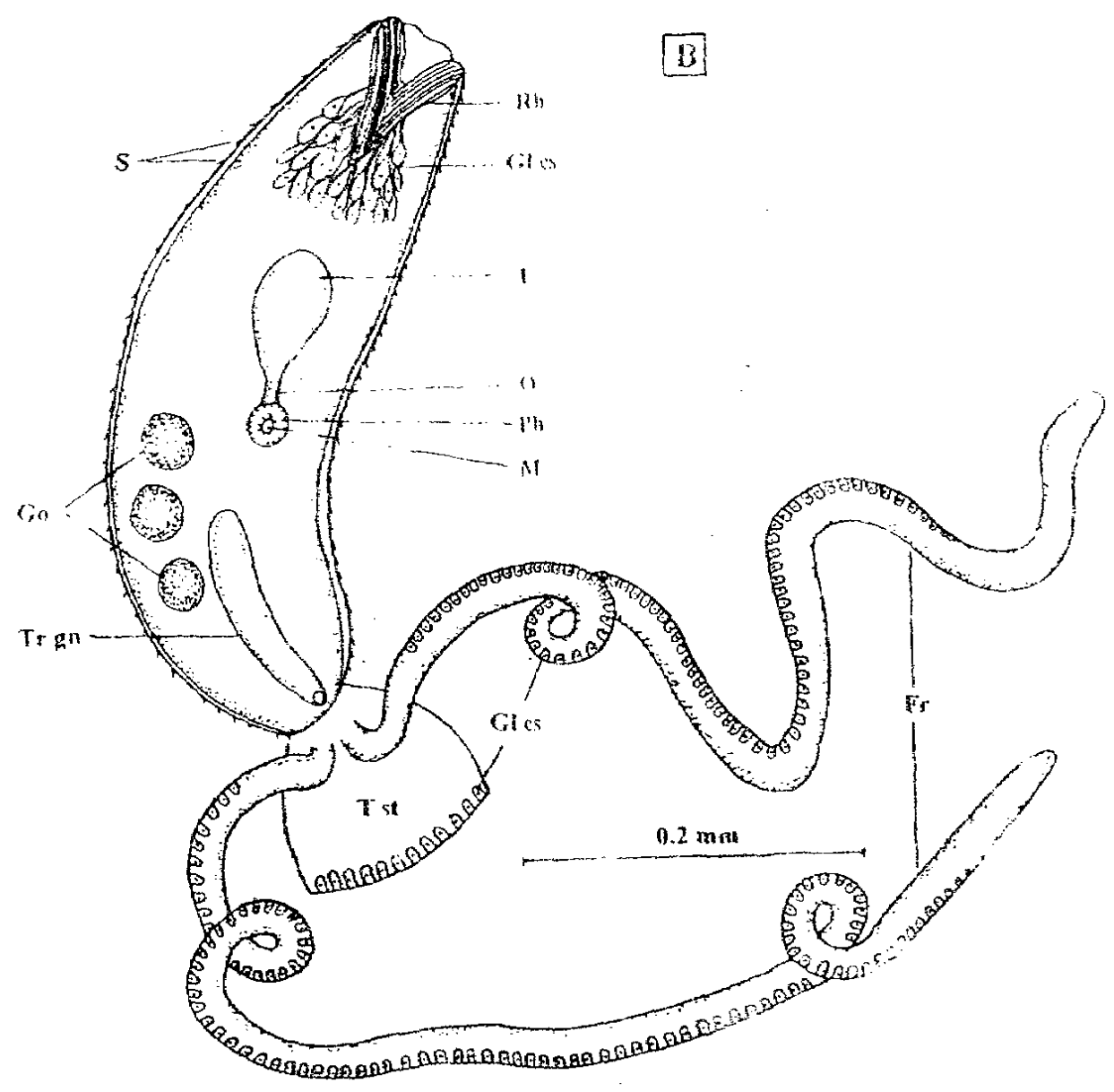

Fig. (2): Schematic drawing showing:

A) A bucephalid sporocyst containing germ balls and cercariae.

B) A single bucephalid cercaria.

D $c r=$ Developing cercariae, $F r=$ Furcae, $G$ bls $=$ Germ balls, $G 0=$ Gonad anlagen,

Gl $\mathrm{cs}=$ Gland cells, $\mathrm{I}=$ Intestine, $\mathbf{M}=$ Mouth, $\mathrm{O}=$ Cesophagus, $\mathbf{P h}=$ Pharynx, $\mathbf{R h}=$

Rhynchus, $\mathrm{S}=$ Spines, $\mathrm{T}$ st $=$ Tail stem. $\mathrm{Tr}$ gn= Rudiments of terminal genitalia 


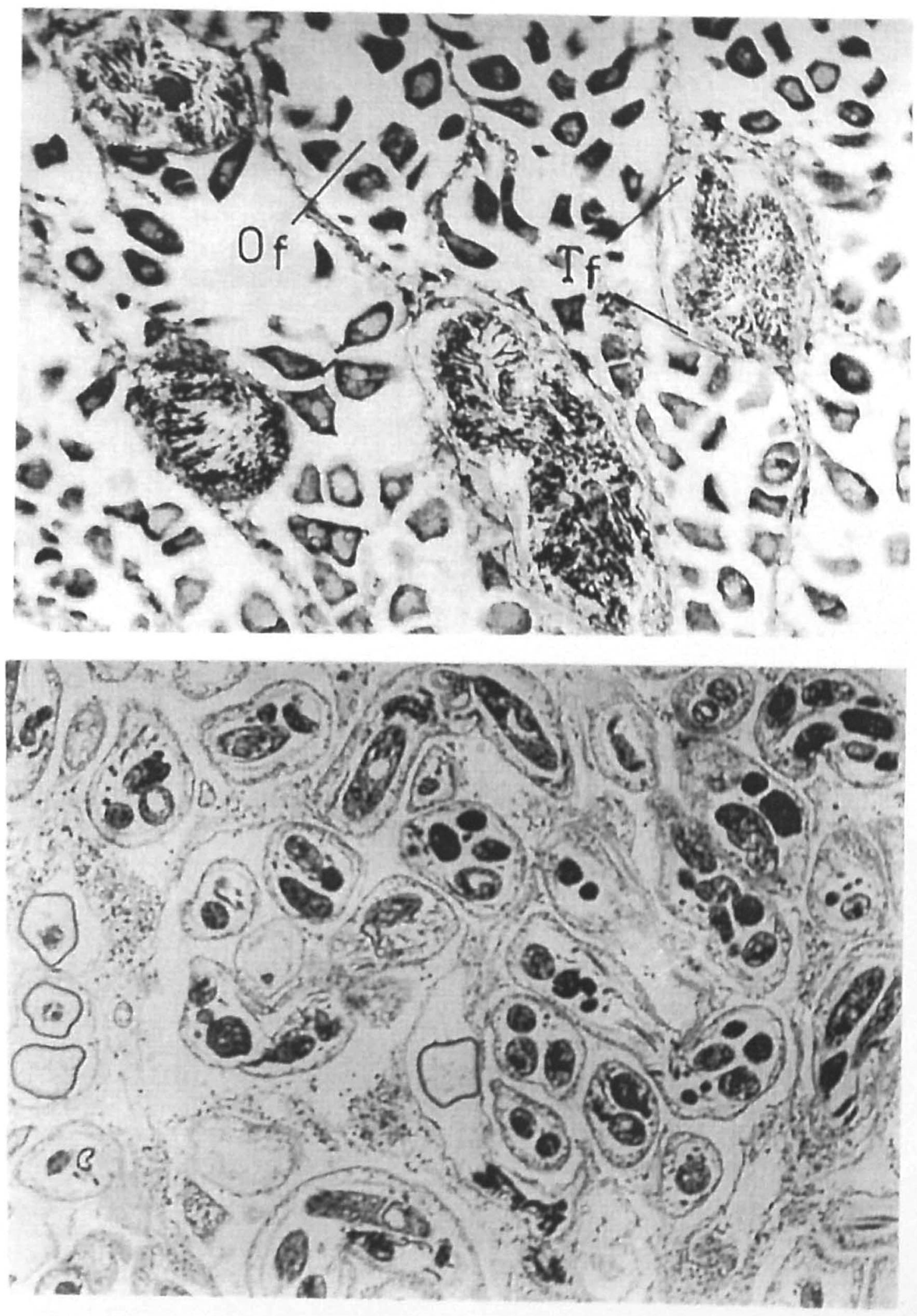

